\title{
Tomasz Kucharski
}

Uniwersytet Mikołaja Kopernika, Toruń

\section{Czy szlachecka Rzeczpospolita miała konstytucję? Przyczynek do rozważań nad wykorzystywaniem ustaleń nauki prawa konstytucyjnego do badań historii ustroju}

DOI: http://dx.doi.org/10.12775/SIT.2014.006

Przedmiot niniejszych rozważań stanowić będzie analiza zasadności stosowania pojęć „konstytucja”, „konstytucjonalizm” czy „konstytucyjność” dla realiów państwa feudalnego na przykładzie Rzeczypospolitej Obojga Narodów (1569, 1572-1795). W pracy stawiamy sobie za cel realizację trzech założeń. Po pierwsze, pragniemy przedstawić wszystkie istotne hipotezy badawcze stawiane w literaturze przedmiotu, które ujmują określone staropolskie akty prawne w kategoriach aktów konstytucyjnych. Po drugie, zamierzamy krytycznie ustosunkować do każdej ze wskazanych teorii, analizując je pod względem historyczno-prawnej, a także typowo prawniczej adekwatności i poprawności. Po trzecie, spróbujemy zaprezentować kilka uwag o charakterze teoretycznym i modelowym, które stanowić będą podsumowanie całości pracy. W tym kontekście postaramy się przede wszystkim ocenić, czy stosowanie kategorii „aktu konstytucyjnego” i „konstytucyjności” jest w ogóle możliwe dla realiów sprzed rewolucji francuskiej (a w przypadku Polski sprzed Sejmu Wielkiego), a jeśli jest możliwe, to według jakich kryteriów i na jakich warunkach powinno się tego dokonywać. 
Punkt wyjścia dla naszych rozważań musi stanowić konstatacja, iż niemożliwe jest odnoszenie wprost do realiów systemu feudalnego terminologii współczesnego prawa konstytucyjnego. Zgodnie $\mathrm{z}$ ogólnie przyjętą definicją konstytucja to $\mathrm{w}$ dzisiejszym systemie prawnym „akt normatywny o najwyższej mocy prawnej w państwie zawierający regulacje określające zasady organizacji państwa, podmiot władzy oraz sposoby sprawowania przezeń władzy, cele i zadania państwa, prawa wolności i obowiązki jednostki oraz zawierający

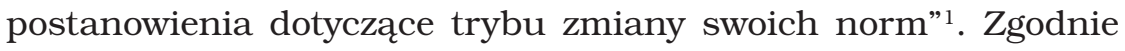
z rezultatami badań historycznych nad genezą współczesnych aktów konstytucyjnych (w zakresie badań nad tzw. nowoczesnym konstytucjonalizmem) ustawy zasadnicze muszą spełniać nie tylko wymóg formalnej wyższości nad innymi źródłami prawa w danym systemie, ale powinny realizować szereg wymogów materialnych (zwłaszcza w zakresie ochrony praw człowieka i obywatela oraz realizacji zasad: suwerenności narodu, równości wobec prawa czy ograniczonego rządu) ${ }^{2}$. Takich kryteriów nie spełnia $z$ pewnością nie tylko żaden akt prawny $z$ epoki feudalnej, ale i wiele konstytucji powstałych pod koniec XVIII wieku i na przestrzeni XIX stulecia. Jeśli zatem w ogóle analizować problem adekwatności kategorii „konstytucyjności” dla realiów historycznych, szczególnie przedoświeceniowych, trzeba odnaleźć i zdefiniować kryteria nieco mniej rygorystyczne. W niniejszym opracowaniu pragniemy ustalić, czy jest to w ogóle możliwe.

Najpierw jednak warto przyjrzeć się wszystkim obecnym na kartach literatury przedmiotu teoriom, które sytuują jakiś akt prawny w pozycji feudalnej konstytucji przedrozbiorowej Polski. Pierwszym takim aktem, którym należy się zająć w omawianym kontekście szczególnie pieczołowicie, są oczywiście Artykuły henrykowskie. Teza, iż stanowiły one coś na kształt „ustawy zasadniczej” Rze-

${ }^{1}$ B. Banaszak, Porównawcze prawo konstytucyjne wspótczesnych państw demokratycznych, Warszawa 2012, s. 44.

${ }^{2}$ Anna Tarnowska pisze w tym kontekście: „choć genezę nowoczesnego konstytucjonalizmu niewątpliwie datować należy na koniec XVIII w., zdecydowana większość konstytucji XIX-wiecznych nie mieści się w tym nurcie”. A Tarnowska, Koncepcja nowoczesnego konstytucjonalizmu $w$ historii prawa, „Studia Iuridica Toruniensia” 2009, t. 5, s. 62-78. 
czypospolitej, jest bardzo rozpowszechniona w literaturze, z całą pewnością jest ona od lat składnikiem polskiej tradycji historyczno-prawnej. Twierdzenie takie promowane jest przez wielu badaczy dziejów prawa Polski przedrozbiorowej, by wspomnieć choćby Władysława Konopczyńskiego ${ }^{3}$, Władysława Sobocińskiego ${ }^{4}$ czy Izabelę Lewandowską-Malec ${ }^{5}$. Teza ta, co szczególnie istotne, stanowi przy tym składnik wielu syntetycznych opracowań dydaktycznych, w tym świeżego, znakomitego skądinąd ujęcia podręcznikowego historii państwa i prawa polskiego, pióra Wacława Uruszczaka ${ }^{6}$. Ostatnio bardzo stanowczo opowiedział się za nią w odrębnej monografii poświęconej Artykułom, Dariusz Makiłła ${ }^{7}$. Niestety żaden z autorów głoszących pogląd o konstytucyjności artykułów bliżej go nie uzasadnia, nie wskazuje argumentów, szczególnie natury prawniczej, na poparcie tej tezy. Nie dysponujemy zatem analizami wskazującymi na konkretne cechy Artykułów, które miałyby przesądzać o ich „konstytucyjnym” charakterze. Więcej nawet, wskazane powyżej prace nie zawierają niestety również wskazania kryteriów, które powinien, zdaniem autorów, spełnić akt prawny z okresu feudalnego, by można go było określić mianem konstytucyjnego.

${ }^{3}$ W. Konopczyński, Konwokacje, w: Studia historyczne ku czci Stanisława Kutrzeby, t. 1. Kraków 1938, s. 253.

${ }^{4}$ W. Sobociński, O ustawie konstytucyjnej Państwa Polskiego z roku 1573 r., „Czasopismo Prawo-Historyczne” 1948, t. 1, s. 75-90.

${ }^{5}$ I. Lewandowska-Malec, Demokracje polskie. Tradycja - wspótczesność oczekiwania, Kraków 2013, s. 93.

${ }^{6}$ Zob.: W. Uruszczak, Historia państwa i prawa polskiego, t. 1: 966-1795, Warszawa 2013, s. 225; M. Kallas, Historia ustroju Polski, Warszawa 2005, s. 123-124; D. Makiłła, Historia prawa w Polsce, Warszawa 2008, s. 60. O Artykułach henrykowskich jako prawach fundamentalnych piszą R. Łaszewski i S. Salmonowicz, Historia ustroju Polski, Torun 2001, s. 50 oraz M. Maciejewski, Historia ustroju i prawa sądowego Polski, Warszawa 2011, s. 53.

7 Zob. D. Makiłła, Artykuły henrykowskie (1573-1576). Geneza-Obowiazywanie - Stosowanie. Studium historyczno-prawne, Warszawa 2012. Autor posługuje się dość często pojęciem „Akt konstytucyjny” (tak zwłaszcza na s. $115 \mathrm{w}$ tekście głównym oraz w przyp. 270), co sugerowałoby pojmowanie przez niego Artykułów w zasadzie jako konstytucji w znaczeniu formalnym. Potwierdzenie tego przypuszczenia stanowi klarowna deklaracja, według której „można przyjąć, że Artykuły henrykowskie były również formalnie pierwszą, polską, pisaną ustawą zasadniczą". Ibidem, s. 499. 
Argumentacja zwolenników tezy o charakterze prawnym Artykułów jako ustawy zasadniczej, zrekonstruowana $z$ ich lapidarnych wskazówek, sprowadza się w zasadzie do prezentacji trzech twierdzeń. Zgodnie $z$ nimi Artykuły należy uznać za feudalną konstytucję Rzeczypospolitej, gdyż:

1. Zostały uchwalone w wyjątkowym i przełomowym dla kształtu staropolskiego systemu ustrojowego czasie (tzn. w toku pierwszego bezkrólewia doby wolnych elekcji).

2. Regulowały doniosłe materie ustrojowe.

3. Cieszyły się specyficzną atencją szlacheckiego społeczeństwa, która przeradzała się w toku długotrwałej ewolucji w przekonanie o ich nadrzędnej pozycji w systemie prawnym.

Ad 1. Niewątpliwie Artykuły henrykowskie stanowiły rezultat szerokiej dyskusji społecznej, toczącej się podczas pierwszego bezkrólewia po wygaśnięciu dynastii Jagiellonów, nad postulatami tzw. poprawy prawa. Celem tego działania nie było jednak zmodyfikowanie czy stworzenie na nowo ustroju politycznego i społecznego szlacheckiej Rzeczypospolitej, ale raczej potwierdzenie i ugruntowanie zdobyczy ruchu egzekucyjnego, a także zabezpieczenie istniejącego już ustroju przed ewentualnymi nadużyciami ze strony nowego, potencjalnie cudzoziemskiego króla. Niebagatelną rolę odegrały tu zarzuty stawiane dwóm ostatnim panującym: Zygmuntowi Staremu i Zygmuntowi Augustowi, którzy byli dość powszechnie oskarżani o łamanie praw szlachty ${ }^{8}$. Trudno byłoby w tym kontekście uznać sejm elekcyjny z 1573 roku za swego rodzaju konstytuantę, powołaną do stworzenia nowej konstrukcji ustrojowej. Widać to zresztą po kształcie samych Artykułów, które nie regulują kompleksowo materii ustrojowych, ale normują sfery życia państwowego szczególnie podatne na nadużycia władzy monarszej.

Ad 2. W konsekwencji wniosków powyższych warto przyjrzeć się bliżej regulacjom Artykułów, szczególnie w kontekście zasad ustrojowych, decydujących o obliczu systemu politycznego Rzeczypospolitej. Jeśli zestawimy treść Artykułów z katalogiem zasad

${ }^{8}$ Szerzej uzasadniamy swoje stanowisko w innym miejscu, por. T. Kucharski, Instytucja egzorbitancji $w$ systemie prawno-ustrojowym Rzeczypospolitej Obojga Narodów, rozdział 1.3, [w druku]. 
ustrojowych Rzeczypospolitej zdefiniowanych przez Uruszczaka, przekonamy się, że bardzo niewiele $z$ nich znalazło swoje, nawet pośrednie odzwierciedlenie w normach omawianego aktu' ${ }^{9}$ Spośród ośmiu zasad ustroju społecznego tylko dwie wyartykułowano w Artykułach expressisverbis: zasadę tolerancji religijnej ${ }^{10}$ oraz wolności obywatelskich szlachty ${ }^{11}$. $Z$ pozostałych norm można by jeszcze wyinterpretować cząstkowe regulacje odnoszące się do zasady równości szlacheckiej ${ }^{12}$. Trudno jednak byłoby uzasadnić tezę,

${ }^{9}$ Wacław Uruszczak ogłosił swoje tezy dotyczące katalogu zasad ustrojowych Rzeczypospolitej w szkicu pt. Zasady ustrojowe Rzeczypospolitej Obojga Narodów, „Czasopismo Prawno-Historyczne”, 2008, z. 2, s.125-156. W założeniu miał to być artykuł dyskusyjny, niestety nie odczekał się szerszego oddźwięku. Autor wymienia osiem zasad ustroju społecznego: podział stanowego społeczeństwa, wolności obywatelskie szlachty, równość szlachty, upośledzenie prawne mieszczaństwa, poddaństwo chłopów, powiązanie państwa i Kościoła katolickiego, tolerancję religijną i poszanowanie praw mniejszości etnicznych. Zdaniem autora było 15 zasad ustroju politycznego: samowładność i niepodległość Rzeczypospolitej, suwerenność narodu szlacheckiego, mieszana (monarchiczno-republikańska) forma rządu, jedność Rzeczypospolitej, podział władzy, ustrój parlamentarny, elekcyjność tronu, nadrzędność prawa, poszanowanie partykularnych odrębności prawnych prowincji i ziem, odpowiedzialność głowy państwa, dożywotniość i niepołączalność urzędów, samorządność, jednomyślność, wolny głos i wolny sprzeciw oraz wybory sędziów. Idem, Zasady, passim; idem, Historia państwa, s. 190-223.

${ }^{10} \mathrm{~W}$ akcie tym występuje jednak w zasadzie nie regulacja pokoju religijnego, a potwierdzenie obowiązywania „Konfederacyi osobliwey”, którą król „obiecuie trzymać wcale wiecznemi czasy”, por. Volumina Legum [dalej: VL], t. 2, wyd. J. Ohryzko, Petersburg 1859-60, s. 160, fol. 918.

${ }^{11}$ Artykuły podkreślają, że władza królów polskich, a zwłaszcza ich działalność prawodawcza miała być oparta „na fundamencie utwierdzenia praw i swobód”. Król „waruie” zatem szlachcie, że będzie respektował „wszystkie przywileie, daniny, zapisy, dożywocia, prerogatywy, wolności y swobody [...] Korony Polskiey y Wielkiego Xsięstwa Litewskiego, iako Ziem do nich należących [...]”. Ibidem, s. 159, fol. 916. W dalszym tekście potwierdzono niektóre $z$ wolności i prawa, ale ich liczba była relatywnie niewielka: z praw cywilnych znajdujemy w zasadzie jedno - o alodialnej własności gruntów, dodatkowo uregulowano jeszcze kilka praw politycznych, m.in.: o partycypacji w wyborze króla, prawie do uczestniczenia w sejmikach i sejmie, czy dostępu do urzędów.

12 Można ją wyinterpretować z przepisu o nadawaniu urzędów jedynie „ludziom statecznym, godnym y zasłużonym, oboyga narodu” - widać wyraźnie, że nie rozróżniano tu szlachty według żadnych kryteriów poza merytorycznymi. 
iż zasady te znajdują swe źródło w Artykułach czy że zostały w nich kompleksowo uregulowane. To raczej treść cząstkowych często norm nawiązuje do istniejących już szerszych zasad, unormowanych wcześniejszymi, szczątkowymi regulacjami prawa stanowionego albo też wynikających zdominującego prawa zwyczajowego. Jeszcze bardziej klarownie wygląda sprawa $z$ zasadami ustroju politycznego Rzeczypospolitej, w Artykułach wyartykułowano wprost jedynie dwie spośród 15 zasad: elekcyjność tronu i odpowiedzialność głowy państwa $^{13}$. W treści norm Artykułów możemy odnaleźć też regulacje o cząstkowym charakterze, stanowiące jedynie luźne nawiązania do istniejących i ugruntowanych już zasad: mieszanej (monarchiczno-republikańskiej) formy rządów, ustroju parlamentarnego i wolnego głosu, podziału władz oraz dożywotności i niepołączalności urzędów ${ }^{14}$. Pozostałe zasady nie znalazły w ogóle odzwierciedlenia w Artykułach, w tym tak istotne jak: zasada samowładności i niepodległości Rzeczypospolitej, suwerenności narodu szlacheckiego, jednomyślności, nadrzędności prawa, poszanowania partykularnych odrębności prawnych prowincji i ziem czy wyboru sędziów. Zresztą treść Artykułów w ogóle ogniskuje się na technicznych aspektach ograniczeń formalnych dla władzy królewskiej, twórcom omawianego aktu zdecydowanie nie przyświecała idea wykreowania kompleksowej regulacji prawa ustrojowego, zwłaszcza o charakterze nadrzędnym względem innych praw. Trudno przy tym przychylić się do twierdzenia Sobocińskiego, który napisał, że mimo iż treść Artykułów nie obejmowała „całości norm ustrojowych” ani nie była

Podobnie rzecz się miała w zakresie regulacji o uwolnieniu gruntów szlacheckich od królewskiego regale górniczego i regulacji potwierdzającej alodialnych charakter tych nieruchomości, a także w zakresie wynagradzania szlachcie służby wojskowej za granicą ( 5 grzywien przez ćwierć roku), niezależnie, czy służyliby w piechocie, czy w jeździe.

${ }^{13}$ Co istotne, przepis dotyczący wypowiedzenia posłuszeństwa został w konstytucjach z 1576 roku wyodrębniony redakcyjnie spośród właściwych Artykułów henrykowskich, pozostał jednak niewątpliwie integralną częścią tego aktu, por. ibidem, s. 163, fol. 922-923.

${ }^{14}$ Pierwsze cztery to interpretacja całości aktu, który dotyczy przede wszystkim relacji między królem a sejmem, ostatnia ma podstawę w konkretnym przepisie, który nakazuje ogólnie zachowanie przez monarchę organizacji urzędów w nienaruszonym stanie. 
„pracą systematyczną”,to przypomina dzisiejsze konstytucje przede wszystkim ze względu na fakt, że znajdowały się w nich regulacje odnoszące się do relacji króla $z$ narodem i państwa jako całością, a zabrakło tam charakterystycznych dla staropolskiego ustawodawstwa „zwykłego” przepisów odnoszących się do poszczególnych części składowych państwa ${ }^{15}$. Przecież - jak wspominaliśmy (co potwierdzają ustalenia nawet głoszącego tezę o ,jedności Rzeczypospolitej” prof. Uruszczaka) - podział terytorialny państwa i odrębności prawne poszczególnych części składowych Rzeczypospolitej stanowiły jedną z podstawowych cech ustroju dawnej Rzeczypospolitej ${ }^{16}$. W konsekwencji argumenty uzasadniające konstytucyjny charakter Artykułów formułowane na podstawie analizy ich treści uważamy za całkowicie bezpodstawne.

Ad 3. Ostatnim, chyba najmocniejszym argumentem, który miałby przemawiać za uznaniem, że Artykuły stanowiły feudalną konstytucję Rzeczypospolitej, jest ich szczególna pozycja w szlacheckiej kulturze prawnej, która zrodziła ewolucyjnie przekonanie o ich nadrzędności w systemie źródeł prawa. Najbardziej chyba dosadnie pisze o tym Lewandowska-Malec: „Reakcja krytyczna narastała wraz $\mathrm{z}$ umacnianiem się przekonania o wyższości norm Artykułów henrykowskich nad zwykłymi konstytucjami. Ewolucja $\mathrm{w}$ tym zakresie była długotrwała, jednak wielce pouczająca [...]. Z czasem [Artykuły - T.K.] nabierały charakteru zasadniczego, kardynalnego, uzyskiwały przewagę w systemie źródeł ówczesnego prawa pospolitego. W tym kontekście stwierdzenie [...], że Artykuły henrykowskie były pierwszą polską "pisaną konstytucją", należy uznać za prawidłowe" ${ }^{17}$.

15 W. Sobociński, O ustawie, s. 78.

16 Por. w tym kontekście niezwykle ciekawe uwagi dotyczące „quasi-federacyjnej” struktury dawnej Rzeczypospolitej autorstwa Z. Naworskiego, Status Prus Królewskich $w$ Rzeczypospolitej Obojga Narodów - ewenement czy reguła, w: Rzeczpospolita państwem wielu narodowości i wyznań XVI-XVIII wiek, red. T. Ciesielski, A. Filipczak-Kocur, Warszawa-Opole 2008, s. 61-80. A także uzasadnienie odrzucenia takiego postrzegania dawnej Rzeczypospolitej przy docenieniu roli partykularnych odrębności - W. Uruszczak, Historia państwa, s. 207.

17 I. Lewandowska-Malec, op.cit., s. 93. 
W tym kontekście zwraca jednak także uwagę brak jakichkolwiek badań odnoszących się do stosunku szlacheckiej opinii publicznej względem Artykułów (szczególnie ujmowanych jako całość, a nie zbiór konkretnych norm w nich zawartych). Na potrzeby niniejszego szkicu nie przeprowadzaliśmy w tym zakresie żadnych szczegółowych kwerend czy głębszych badań źródłowych, trudno zatem o jakiekolwiek stanowcze wnioski. Warto jednak nadmienić, że nawet pobieżny przegląd dostępnego materiału wskazuje, iż na przełomie XVI i XVII wieku stosunek do Artykułów był rzeczywiście wyjątkowy. Dla przykładu szlachta średzka w instrukcji z 1604 roku określała je mianem firmamantum publicae libertatis ${ }^{18}$. Podobne znaczenie mają podnoszone przez szlachtę postulaty realizowania Artykułów w toku sporów politycznych, szczególnie I poł. XVII wieku ${ }^{19}$. Na podstawie tego materiału trudno wysnuwać jakiekolwiek konkluzywne wnioski, przytoczone opinie mają bowiem charakter zdecydowanie polityczny, trudno ocenić, czy aprobata dla nich była powszechna, a także jaką miały one realnie siłę oddziaływania na społeczeństwo. Widoczne jest jednak, że dowodzą one dużego znaczenia regulacji Artykułów, nie wskazują jednak na ich moc prawną czy miejsce w hierarchii aktów prawnych. Szczególna rola polityczna i atencja opinii publicznej dla Artykułów (choćbyśmy nawet założyli, że dotyczyła tego aktu w całości, a nie tylko jego najważniejszych norm, i że była zjawiskiem trwałym i niezmiennym na przestrzeni 200 lat obowiązywania omawianego aktu) to argumenty zdecydowanie niewystarczające, by uzasadnić czy choćby uprawdopodobnić twierdzenie o konstytucyjnym charakterze Artykułów. Co w tym kontekście szczególnie interesujące, w zasadzie wszyscy badacze będący zwolennikami tej tezy podkreślają, iż z formalnego punktu widzenia moc prawna Artykułów nie była większa aniżeli innych staropolskich aktów prawnych, a ich „nadrzędność” wyrażać się

18 Akta sejmikowe województw poznańskiego i kaliskiego, t. 1, cz. 1, wyd. W. Dworzaczek, Poznań 1957, s. 263.

19 Prezentuje je, choć bardzo wybiórczo i pobieżnie, D. Makiłła, op.cit., s. 403-497. Nawet jednak ten autor wspomina, iż od połowy XVII wieku rzadko powoływano się na Artykuły, ibidem, s. 289. 
miała jedynie $\mathrm{w}$ postrzeganiu ich $\mathrm{w}$ ramach kultury prawnej staropolskiego społeczeństwa ${ }^{20}$.

Drugim aktem, który można rozpatrywać w kategoriach feudalnej konstytucji, są z całą pewnością pacta conventa od roku $1632^{21}$. Data ta wyznacza cezurę dla ukształtowania się nowego modelu paktów, w których rola zobowiązań osobistych monarchy ulega zmniejszeniu, a miejsce naczelne zajmują przepisy ustawowe, zgodnie $z$ utrwaloną tradycją historiograficzną, transponowane przede wszystkim $z$ Artykułów henrykowskich ${ }^{22}$. W konsekwencji pacta miały zawierać $\mathrm{w}$ sobie normy prawne na równych płaszczyznach wyznaczające granice uprawnień i zakres obowiązków królewskich. W konsekwencji, choć katalog tych uregulowań nie był może kompleksowy, to zawierał jednak w sobie przepisy najważniejsze, newralgicznie dla prawidłowego funkcjonowania państwa. Uruszczak pisze w tym kontekście: „Artykuły henrykowskie zostały połączone z osobistymi zobowiązaniami króla elekta w jeden akt [...]". Akt powstały w ten sposób to „podstawowe Privilegium Regni” i „suigeneris konstytucja polska, aż do Konstytucji 3 maja”"23.

${ }^{20}$ Por. W Sobociński, O ustawie, s. 78.

${ }^{21}$ Teksty paktów: Władysława IV: VL, t. 3, s. 362-366, fol. 762-772; Jana Kazimierza: VL, t. 4, s. 93-97, fol. 193-203; Michała Wiśniowieckiego: VL, t. 5, s. 13-21, fol. 18-36; Jana Sobieskiego: VL, t. 5, s. 139-146, fol. 263-279; Augusta II: VL, t. 6, s. 14-26, fol. 16-45; Augusta III: VL, t. 6, s. 301-310, fol. 620-639 oraz Stanisława Augusta Poniatowskiego: VL, t. 7, s. 97-103, fol. 199-212. Podobny charakter noszą obie redakcje paktów Stanisława Leszczyńskiego, które z powodów politycznych nie weszły w życie, zob. Biblioteka Zakładu im. Ossolińskich, sygn. 652/I, k. 263-281; Archiwum Główne Akt Dawnych w Warszawie, Archiwum Radziwiłłów, dz. II-62, s. 33-34 [149-150].

${ }^{22}$ Pomijamy w niniejszych rozważaniach nasze sceptyczne stanowisko wobec teorii o włączaniu Artykułów do paktów, które bliżej uzasadniamy w innym miejscu, por. T.Kucharski, Modyfikacja charakteru prawnego paktów konwentów po roku 1632, w: Ex contractu, ex delicto, z dziejów prawa zobowiązań, red. M. Mikuła, K. Stolarski, Kraków 2012, s. 89-109.

${ }^{23}$ W. Uruszczak, Historia państwa, s. 225. Dość osobliwą teorię, odmienną od zapatrywań prof. Uruszczaka, głosi Dariusz Makiłła, według którego Artykuły obowiązywały od 1632 roku „dwutorowo” - z jednej strony pozostały nadal aktem prawnym o charakterze konstytucji państwa, a jednocześnie występowały jako część składowa pacta conventa, które stawały się w ten sposób „zasadniczym 
Na podstawie powyższego widać zatem, iż konstytucyjny charakter paktów według niektórych badaczy staropolskiego ustroju miał być uzależniony od takiegoż statusu Artykułów henrykowskich (co udało nam się, jak mamy nadzieję wiarygodnie, zakwestionować powyżej). Szczególna rola pacta conventa przybierała tu zatem znów charakter jedynie polityczny, nie miały one zajmować formalnie nadrzędnej pozycji w systemie prawnym. W konsekwencji ich klauzule można było „nowelizować” za pomocą zwykłej konstytucji sejmo$\mathrm{wej}^{24}$. Ponadto normy pacta conventa zaczerpnięte $\mathrm{z}$ imperatywnych norm ustawowych stanowiły często potwierdzenie przywilejów generalnych lub konstytucji sejmowych z okresu wcześniejszego, trudno tu zatem o wskazanie hierarchicznej wyższości jednych nad drugimi $^{25}$. Gotfryd Lengnich podkreśla zresztą wprost równą moc prawną pacta conventa i zwykłych konstytucji ${ }^{26}$. Warto przy tym pamiętać, że regulacje pacta conventa, podobnie jak Artykułów (a może nawet $\mathrm{w}$ nieco większym stopniu) nie miały charakteru kompleksowego. Był to dość przypadkowy katalog norm dotyczących monarchy, zatem większość sfer funkcjonowania państwa

instrumentem określającym charakter królewskiego panowania”, D. Makiłła, Artykuły henrykowskie, s. 488.

${ }^{24}$ Zob. także: W. Sobociński, Pakta konwenta, Kraków 1939, s. 175-176.

${ }_{25}$ Tak np. konstytucje sejmu niemego zmieniały klauzule pacta conventa dotyczące m.in. gwardii królewskiej, por. VL, t. 6, s. 17, fol. 23 i s. 117, fol. 238-239. Inną egzemplifikacją omawianego zjawiska może być klauzula z pacta conventa Władysława IV w zakresie prawa o wolnej elekcji, która gwarantowała „wolne obieranie [...] według praw, przywileiów y konstytucyi wszystkich deliberaelectio uczynionych, tak dawnych, iako i świeżych 1607, 1609, 1631, y według specjalnego przywileiu anni 1607, y potym na seymie 1631, za ś. Pamięci K.I.Mci Zygmunta Trzeciego, Rzeczypospol. danego i w konstytucyi ingrosowanego, zostawało", VL, t. 3, s. 363, fol. 763. W późniejszych redakcjach do identycznie brzmiącej formuły dodawano jeszcze wskazanie na klauzulę o wolnym obieraniu z pacta conventa poprzedników. Sugeruje to wprost ich równorzędność norm $z$ innymi konstytucjami. Warto dodać, że już uchwała sejmu z 1607 roku określała pacta conventa mianem konstytucji sejmowej, co wskazuje, przynajmniej do pewnego stopnia, na utożsamianie tych źródeł prawa, por. VL, t. 2, s. 434 fol 1599.

${ }^{26}$ G. Lengnich, Prawo pospolite Królestwa Polskiego, tłum. M. Moszczeński, t. 1, Kraków 1761, s. 5. 
pozostała nieuregulowana za pomocą ich klauzul. O nietraktowaniu pacta conventa w kategoriach konstytucji świadczy również ich pozostawienie w systemie źródeł prawa, pod rządami Konstytucji 3 maja $^{27}$.

Dodatkowym argumentem za uznaniem pacta conventa za akt prawny o szczególnym, nadrzędnym charakterze prawnym mogłaby stanowić praktyka odczytywania ich treści na początku każdego kolejnego sejmu walnego. Podkreślić należy, iż był to przede wszystkim instrument kontrolny (co wynikało $z$ przyznania posłom i senatorom prawa do „przymawiania się” do poszczególnych klauzul $\mathrm{z}$ pacta conventa w razie dostrzeżenia ich nierespektowania) ${ }^{28}$. Jednakże rytuał ten miał również na celu uzmysłowienie monarsze jego podstawowych obowiązków, przypomnienie mu, jakim państwem i społeczeństwem oraz według jakich prawideł powinien władać. Jest to jednak przesłanka dość wątła i mogłaby stanowić jedynie wzmocnienie dla silnej argumentacji, której - jak staraliśmy się pokazać - zdecydowanie brakuje.

Kolejnymi aktami ustrojowymi o fundamentalnym znaczeniu, którym starano się przydać charakter staropolskiej konstytucji są oczywiście uchwały sejmowe stanowiące kodyfikację tzw. praw kardynalnych $z$ roku 1768 wraz $z$ uzupełnieniem $z$ roku $1775^{29}$. Akty te mają niewątpliwie istotne znaczenie dla staropolskiego prawa co najmniej $z$ trzech powodów:

1. Miały charakter reguł kardynalnych czy fundamentalnych, cosugeruje, że mamy tu do czynienia $z$ normami uważanymi za „zawias”, na którym zawisła „wolność pospolita”.

2. Stanowiły zestaw praw formalnie nienaruszalnych, tzn. niezmiennych.

${ }^{27}$ Występowały one notabene we wszystkich projektach ustaw zasadniczych powstających w tym okresie - jedynie w projekcie Scypiona Piattollego zabrakło o nich wzmianki, ale dopisał ją opiniujący i korygujący projekt Ignacy Potocki, por. B. Leśnodorski, Dzieło Sejmu Czteroletniego 1788-1792: studium historyczno-prawne, Warszawa 1951, s. 158, 175, 180, 184, 187, 199, 208.

28 VL, t. 6, s. 303, fol. 622.

${ }^{29}$ Historia państwa i prawa Polski, red. J. Bardach, t. 2, Warszawa 1971, s. 498; W. Uruszczak, Historia państwa, s. 225. Treść praw kardynalnych - zob. VL, t. 7, s. 277-285, fol. 595-606; t. 8, s. 49-50, fol. 62-63. 
3. Byłyznacznie bardziej kompletne w treści aniżeli inne staropolskie akty dotyczące problematyki ustrojowej, z Artykułami henrykowskimi i pacta conventa włącznie.

Ad 1. Z pierwszym argumentem trudno wchodzić w spór, od połowy XVII wieku zaczęto bowiem uważać, iż pewne regulacje prawne Rzeczypospolitej mają charakter kluczowy dla funkcjonowania staropolskiego ustroju politycznego i społecznego, a ich zmiana musi spowodować upadek państwa. Oczywiście katalog zwyczajowych zasad tego typu zmieniał się w ciągu XVII i XVIII wieku, zwłaszcza że poszczególni autorzy konstruowali własne teorie na ten temat, a zaliczenie do grupy kardynalnych takiego bądź innego aktu czy przepisu było uzależnione od proweniencji ideowej i indywidualnych zapatrywań twórcy bądź też sytuacji politycznej, w której dany katalog formułowano i prezentowano opinii publicznej ${ }^{30}$.

Ad 3. Trudno byłoby także podejmować polemikę $z$ trzecim argumentem. W ramach praw kardynalnych widać wyraźne uregulowanie zasad ustrojowych Rzeczypospolitej, pominiętych milczeniem w Artykułach henrykowskich, czy kolejnych redakcjach pacta conventa. Wprost uregulowano tu zasadę wolności osobistej szlachty (szczególnie nietykalności osobistej i majątkowej), upośledzenia prawnego mieszczan, poddaństwa chłopów, naczelnego stanowiska Kościoła katolickiego i jego powiązania instytucjonalnego $\mathrm{z}$ państwem, ustroju parlamentarnego, jednomyślności, wolnego głosu i wolnego sprzeciwu, dożywotniości urzędów państwowych, poszanowania partykularnych odrębności prawnych.

${ }^{30} \mathrm{~Np}$. anonimowy autor $\mathrm{z}$ II poł. XVII wieku wymienia jako kardynalne następujące prawa: wolną elekcję królów, odbywaną trybem viritim; iusvetandi; przywilej jedlneński Władysława Jagiełły (neminemcaptivabimus); zasady rozdawania wakansów; istnienie niezależnej od króla, najwyższej instancji sądowej - Trybunałów Koronnego i Litewskiego (które autor określa jako pupilla libertatum nostrarum); monetarny monopol państwowy (sic!); zasada równości wewnętrznej stanu szlacheckiego (zwana przez autora de iure aequalitatis). Dyskurs o eksorbitancyjach, w: Pisma polityczne z czasów panowania Jana Kazimierza Wazy 1648-1668 r., t. 3, Wrocław-Warszawa 1991, s. 336-361. Mniej więcej w tym samym czasie poseł Mikołaj Pękosławski wymienia jako kardynalne i nieodmienne: wolną elekcję, liberum veto oraz przywilej neminemcaptivabimus. S. Ochmann-Staniszewska, Z. Staniszewski, Sejm Rzeczypospolitej za panowania Jana Kazimierza Wazy, t. 1, Wrocław 2000, s. 423. 
Ad 2. Jedynym problematycznym argumentem jest przekonanie, iż prawa kardynalne ze względu na brak możliwości ich formalnej zmiany stanowiły normy o charakterze nadrzędnym w systemie źródeł prawa. By wyjaśnić ten problem, warto zerknąć do treści samych skodyfikowanych praw kardynalnych. W arendze wskazano, iż cel uchwały z 1768 roku to „raz na zawsze trwale ubezpieczyć formam panowania, y wolności”. Realizacja tego postulatu miała się sprowadzać do uchwalenia katalogu praw „nigdy odmienić się nie mogących”, a także tych, „które tylko perunanimitatem na Seymach walnych decydowane być maią" ${ }^{31}$. Dostrzec tu można wyraźną intencję twórców wspomnianego katalogu. Sprowadzała się ona nie do chęci kompleksowego uregulowania ustroju państwowego, ale do jego zabezpieczenia przed ewentualną niepożądaną zmianą. Ich istota polegała zatem nie na tym, że były formalnie nadrzędne w systemie prawnych, ale sprowadzała się do tego, że stanowiły dodatkową, zgodną $z$ tradycją naprawy egzorbitancji gwarancję utrwalonego porządku. Dlatego prawa te nie stały wyżej od innych, a ich newralgiczny charakter spowodowany był zagrożeniem ich uchylenia. Uchwalenie tekstu praw kardynalnych w 1768 roku nie wynikało $z$ intencji formalnego postawienia pewnych norm na szczycie hierarchicznej struktury źródeł prawa. Nie naruszały one bowiem ogólnych zasad obowiązujących w okresie wcześniejszym, nie wprowadzały zatem wyłączności prawa pisanego, pozwalały nadal uwzględniać zwyczaje i prawo zwyczajowe,abstrakcyjne reguły słuszności czy konieczności. W konsekwencji uchwała z 1768 roku stanowiła nie tyle źródło zawartych w niej norm prawnych, ale raczej ich potwierdzenie i dodatkową gwarancję dla ich przestrzegania. Prawa mające status kardynalnych nie potrzebowały bowiem uchwały sejmowej szczególnego rodzaju, żeby uzyskać status kardynalnych. Przeciwnie - to właśnie ich szczególna rola i zagrożenia w postaci reformatorskich inicjatyw Czartoryskich (a także kierunku polityki mocarstw ościennych) zdecydowały o tym, że podjęto decyzję o ich skodyfikowaniu. Nie ulega jednak wątpliwości, że prawa kardynalne zbliżały się, w pewnym stopniu przynajmniej, do konstrukcji nowoczesnego aktu konstytucyjnego i choć ich twórcy

${ }^{31}$ VL, t. 7, s. 277, fol. 596. 
wywodzili się z konserwatywnego obozu politycznego, to stanowiły one krok milowy na drodze ku Konstytucji 3 maja. Zresztą nawet twórcy reform Sejmu Wielkiego po długich sporach zaadoptowali ideę praw kardynalnych do nowego porządku ustrojowego ${ }^{32}$.

Oczywiście możliwe jest jeszcze nieco inne podejście do problemu konstytucji Rzeczypospolitej. Można mianowicie uznać, iż ustrój Polski przedrozbiorowej opierał się na konstytucji w znaczeniu materialnym, na którą składał się szeroki katalog aktów prawnych regulujących materię ustrojową. Taki pogląd prezentuje np. Bogusław Banaszak: „W średniowieczu także występują akty zajmujące szczególne miejsce w systemie źródeł ówczesnego prawa. Tytułem przykładu można wymienić [...] pochodzący z $1374 \mathrm{r}$. przywilej koszycki w Polsce. W późniejszych stuleciach również bez trudu znaleźć możemy akty prawne odgrywające znaczącą rolę ustrojową. Możemy tu wskazać choćby na polską Konstytucję Nihil Novi z 1505 r. czy też tzw. Artykuły henrykowskie z 1573 r." ${ }^{33}$. Oczywiście traktując tę sprawę poważnie, należałoby znacznie poszerzyć wskazany, jak się zdaje, jedynie egzemplifikacyjnie przez prof. Banaszaka katalog aktów, który powinien zawierać pełen zestaw szlacheckich przywilejów z krakowsko-jedneńskim i nieszawskim na czele. Nie należyponadto zapominać o innych aktach rozstrzygających ważkie ustrojowe kwestie m.in.: tekście Modus Coronandi z 1434 roku, statutach o wolnej elekcji z 1530 i 1538 roku, wszystkich aktach unii polsko-litewskich (ze szczególnym uwzględnieniem konstytucji

${ }^{32}$ Wspomina o tym często w swej pracy o ustawodawstwie Sejmu Wielkiego B. Leśnodorski, op.cit., passim.

${ }^{33}$ B. Banaszak, Prawo konstytucyjne, Warszawa 2008, s. 51-52. Zob. też: M. Minda, Źródła i geneza prawa elekcyjnego $w$ początkach Rzeczypospolitej Obojga Narodów - pisemna wersja referatu wygłoszonego na konferencji naukowej „Wolna elekcja w dawnej Rzeczypospolitej - procedura, przebieg, publicystyka" (materiał został nam udostępniony dzięki uprzejmości organizatorów konferencji); W. Uruszczak, Historia państwa, s. 159. Analogiczna koncepcja przyświecała również, jak się zdaje, twórcom wystawy w Trybunale Konstytucyjnym pt. Konstytucje Rzeczypospolitej XVI-XX wiek (materiał dostępny na stronie www.trybunal.gov, dostęp: 20 listopada 2013 r.), na której prezentowano oryginały dokumentów: uchwał sejmu radomskiego z 1505 roku, Statutu łaskiego z 1506 roku, Aktu Konfederacji Generalnej Warszawskiej, Artykułów henrykowskich oraz pierwszych pacta conventa z 1573 roku. 
sejmu lubelskiego z 1569 roku), Ordynacji Trybunału Koronnego z 1578 roku, regulacjach napominania monarchy zawartych w konstytucjach $z$ lat 1607 i 1609 czy konstytucjach amortyzacyjnych z 1635 roku (rozstrzygających za zgodą Stolicy Apostolskiej o możliwościach obrotu dobrami ziemskimi w Rzeczypospolitej, a w konsekwencji o pozycji prawnej i majątkowej Kościoła katolickiego) i o wielu innych aktach. Co więcej, do wspomnianego katalogu należałoby oczywiście zaliczyć wszystkie teksty pacta conventa.

Zaprezentowane ma niestety kilka wad. Po pierwsze, konstrukcja niepisanej brytyjskiej konstytucji materialnej jest tworem w zasadzie współczesnym, do XIX wieku nieznanym angielskiej doktrynie prawnej. Konstrukcję konstytucji Wielkiej Brytanii sformułował Albert V. Dicey w pracy Wstęp do nauki o prawie konstytucyjnym, wydanej w roku 1885. Autor zaliczył w poczet owej konstytucji zasady ustrojowe wynikające jego zdaniem $z$ ustaw, ale także konwenansów konstytucyjnych i precedensów. Co istotne, ta konstrukcja teoretyczna została zaakceptowana i wykorzystana przez judykaturę ${ }^{34}$. Dzięki temu omawiana teoria na gruncie angielskim przeszła długotrwałą ewolucję i została zaakceptowana przez społeczeństwo, elity polityczne i sądy. W przypadku Rzeczypospolitej zabory przerwały ewolucję staropolskiego ustroju, uniemożliwiając potencjalne zaistnienie procesów analogicznych do angielskich.

Poza tym specyfiką wymienionych przez nas egzemplifikacyjnie staropolskich aktów prawnych dotyczących ważkich materii ustrojowych jest to, że nie wydawano ich jako „konstytucyjnych”, a traktowano raczej jako zbiory zwykłych norm prawnych. Konsekwencją tego stanu rzeczy był fakt, że np. akty, które polska historiografia nazywa przywilejami: koszyckim, jedneńsko-krakowskim czy nieszawskim, zawierają, poza fundamentalnymi rozstrzygnięciami dotyczącym wolności szlachty, także wiele innych, mniej istotnych regulacji z zakresu np. prawa sądowego. Podobnie sprawa wygląda w przypadku Artykułów henrykowskich, które także zawierały różnorodne normy, od fundamentalnych dla ustroju państwa, do mniej istotnych, szczegółowych i cząstkowych rozwiązań. Co istotne, wiele fundamentalnych zasad ustrojowych Rzeczypospolitej, by

${ }^{34}$ B. Banaszak, Porównawcze prawo konstytucyjne, s. 46. 
wspomnieć choćby źrenicę wolności szlacheckiej, tzn. liberum veto, funkcjonowało $z$ powodzeniem w praktyce ustrojowej Rzeczypospolitej, choć w zasadzie nie znajdowało klarownej podstawy prawnej w normach pisanych aktów prawnych.

Zastanawiające jest, że w polskich nauce historii, historii prawa czy też prawa konstytucyjnego nad wyraz trudno znaleźć jakikolwiek głos krytyczny lub choćby sceptyczny wobec traktowania Artykułów henrykowskich, pacta conventa po 1632 roku bądź kolejnych redakcji praw kardynalnych jako „aktów konstytucyjnych” czy „pierwszych polskich pisanych konstytucji”. Jedyna taka opinia, jaką udało nam się odnaleźć, wyrażona została w recenzji podręcznika napisanego przez Mariana Kallasa pióra Jacka Matuszewskiego ${ }^{35}$. Autor wskazuje przede wszystkim na niezasadność omawianej tezy w kontekście przyjętej i utartej w literaturze przedmiotu periodyzacji dziejów polskiego ustroju. Niewątpliwie trafnie wskazuje, iż „uznanie Artykułów za konstytucję wymagałoby w konsekwencji przyjęcia, że państwo szlacheckie już od 1573 r. stało się monarchią konstytucyjną [...]". Jest to wyraz poglądów w zasadzie powszechnie przyjętych, które upatrują początków procesu przekształcania się Rzeczypospolitej w monarchię konstytucyjną u progu epoki stanisławowskiej, a za właściwe ustanowienie tej formy rządów przyjmują rok 1791 i uchwalenie Konstytucji trzeciomajowej ${ }^{36}$. Takie spojrzenie na wspomniany problem należy uznać za trafne, forma ustroju państwa w postaci monarchii konstytucyjnej, znana przecież i dzisiaj, charakteryzuje się przecież istnieniem $z$ zasady dziedzicznej monarchii, gdzie władza Korony, a także organów przedstawicielskich narodu jest opisana i ograniczona przez normy ustawy zasadniczej ${ }^{37}$.

35 J. Matuszewski, Czy podręcznik powinien być słuszny czy raczej dobry? W zwiazku z praca Mariana Kallasa „Historia ustroju Polski”, Wydawnictwo Naukowe PWN, Warszawa 2005, „Czasopismo Prawno-Historyczne” 2007, t. 58 , z. 1, s. 301 .

${ }^{36}$ Juliusz Bardach nazywa ten okres: „Próba ukształtowania monarchii konstytucyjnej w dobie rozbiorów”, początek tego okresu datuje na „siódmy dziesiątek XVIII w.”. Historia państwa, t. 1, s. 20.

${ }^{37} \mathrm{Z}$ pojęcia monarchii konstytucyjnej rezygnuje w swej nowej periodyzacji Uruszczak, nazywając formę państwa w Polsce okresu stanisławowskiego Rzecz- 
W dalszej części wywodu prof. Matuszewski słusznie zauważa, iż pojęcie „konstytucji” o skonkretyzowanym znaczeniu prawnym stanowi rezultat ewolucji form ustrojowych i instytucji prawa ustrojowego, na co historyk prawa powinien kłaść szczególny naciska, tzn. „winien wskazywać, jak rozwijały się poszczególne instytucje prawa publicznego, a nie traktować je jako zjawisko trwałe [...], wręcz ahistoryczne" 38 .

Głos prof. Matuszewskiego, choć ważny i zasadny, nie stanowi kompleksowego rozwiązania problemu badawczego, jest to bowiem jedynie polemika zawarta w recenzji podręcznika akademickiego. W konsekwencji autor nie porusza tu kwestii najważniejszych, mianowicie: czym jest konstytucja, jakie cechy powinien posiadać akt tego typu i czy możliwe jest wskazanie takiego ich katalogu, który pozwoliłby na zastosowanie omawianej kategorii do realiów państwa feudalnego.

By odpowiedzieć na pytanie, warto zestawić wskazywane akty prawne $z$ niewątpliwie pierwszą polską konstytucją, uchwaloną w trakcie obrad Sejmu Czteroletniego, zwaną Konstytucją 3 maja. Składały się na nią Ustawa rządowa z 3 maja 1791 roku, dołączone do niej ustawy okołokonstytucyjne (zwłaszcza: o sejmach, o sejmikach i o miastach królewskich), a także akty: Zaręczenia

pospolitą instatureformandi. Autor używa co prawda w odniesieniu do rządów Zygmunta Starego i Zygmunta Augusta określenia „monarchia parlamentarna” (a dla lat 1569 i 1672-1648 w wersji „monarchia elekcyjno-parlamentarna”). W Uruszczak, op.cit., s. 32-33. Pojęcia te mają określone konotacje na gruncie teorii państwa, monarchia parlamentarna stanowi odmianę monarchii konstytucyjnej. Co ważne dla rozważań niniejszych, prof. Uruszczak używa jednak wspomnianej frazy do okresu sprzed powstania Artykułów. Poza tym określenie „monarchia parlamentarna” ma tu charakter raczej deskryptywnego i lapidarnego ujęcia pewnego fenomenu na potrzeby dydaktyczne aniżeli celowego zastosowania określenia typowo prawnego, przejętego $z$ nauki teorii państwa.

38 J. Matuszewski, op.cit., s. 301. Z takich założeń właśnie ukształtowała się teoria o „nowoczesnym konstytucjonalizmie”, kojarząca zjawisko powstawania ustaw zasadniczych dopiero z epoką oświecenia jako reakcją na zjawisko arbitralnych rządów charakterystycznych dla feudalnych monarchii absolutnych, a także wyraz specyfiki polityki i klimatu intelektualnego tamtej epoki. Por. A. Tarnowska, op.cit., passim. 
wzajemnego Obojga Narodów i Deklaracji Stanów Zgromadzonych ${ }^{39}$ oraz pacta conventa (tymczasowo obowiązywać miała redakcja poprawionych paktów Stanisława Augusta, w przyszłości miały one zostać zastąpione stałym tekstem wynegocjowanym $\mathrm{z}$ dynastią saską). Co ciekawe, centralny akt konstytucji - Ustawa rządowa, tkwiąc w uwarunkowaniach semantycznych okresu poprzedniego, nie nosi nazwy „konstytucja”, albowiem była ona zarezerwowana dla wszelkich aktów uchwalanych zgodną wolą trzech stanów przez sejm walny $^{40}$. Stąd w celu odróżnienia twórcy nowego porządku zastosowali pojęcie „ustawa”, o tyle może niefortunnie, że w okresie wcześniejszym stosowano je na określenie aktów prawnych wydawanych przez urzędników, często w sprawach mało istotnych. Co ciekawe, w treści samej Ustawy rządowej sięgnięto do terminu „konstytucja”, ale użyto go w dwu różnych znaczeniach. Na samym wstępie pojawia się on w rozumieniu odmiennym zarówno od tradycyjnie staropolskiego synonimu każdego aktu ustawodawczego, jak i nowoczesnego określenia aktu o charakterze nadrzędnym w systemie prawnym. We frazie, w której twórcy ustawodawstwa trzeciomajowego przekonują, iż ich celem jest: „ugruntowanie i wydoskonalenie Konstytucyi Narodowej”, pojęcie „konstytucja” oznacza w zasadzie całokształt stosunków prawnych i społecznych w państwie, stano-

39 Znawca problematyki Zbigniew Szcząska, opisując relacje między Ustawą rządową a pozostałymi uchwałami Sejmu Wielkiego, podzielił te ostatnie na trzy grupy. W skład pierwszej wchodzić miał tylko jeden akt zatytułowany Miasta nasze królewskie, stanowiący na mocy samej Ustawy rządowej jej integralną część składową. Na drugą grupę składać się miały akty „ściśle związane” z Ustawą rządową, tzn.: Prawo o sejmikach oraz Deklaracja Stanów Zgromadzonych i Zaręczenie wzajemne Obojga Narodów. Trzecią grupę stanowić miał liczny katalog „ustaw wykonawczych” do Ustawy rządowej, autor wskazuje tu m.in.: Prawo o sejmie, Prawo o sądach sejmowych, Prawo o sejmie konstytucyjnym extraordynaryjnym, Ustawę o Straży, Ustawę osądzie ziemiańskim, Ustawę o sądzie trybunalskim. Zob. Z. Szcząska, Ustawa Rządowa z 1791 r., w: Konstytucje polskie. Studia monograficzne z dziejów polskiego konstytucjonalizmu, red. M. Kallas, Warszawa 1990, s. 47.

${ }^{40}$ W. Uruszczak, Historia państwa, s. 228-229; S. Grodziski, Sejm dawnej Rzeczypospolitej jako najwyższy organ ustawodawczy. Konstytucje sejmowepojęcie i próba systematyki, „Czasopismo Prawno-Historyczne” 1983, z. 1; T. Kucharski, Konstytucje „egzorbitancyjne” w Rzeczypospolitej w latach 1607-1648. Zarys problematyki, „Czasopismo Prawno-Historyczne”, 2012, z. 2. 
wiąc synonim słowa „ustrój”"11. Dopiero w końcówce wprowadzenia do Ustawy rządowej i w dalszym jej tekście znajdujemy właściwe, oświeceniowe znaczenie omawianego terminu.

Z punktu widzenia naszych rozważań istotniejsze jednak niż uwagi typowo terminologiczne są rozważania ogniskujące się na charakterze prawnym uchwał Sejmu Wielkiego i nowym porządku źródeł prawa, który został podówczas wprowadzony na grunt prawa Polski przedrozbiorowej. W Ustawie rządowej podkreślono expressis verbis: „do [...] konstytucyi dalsze ustawy teraźnieyszego seymu we wszystkim stosować się maią" ${ }^{2}$. Konstytucja miała być zatem aktem nadrzędnym nad innymi źródłami prawa, mamy tu zatem do czynienia $z$ hierarchiczną strukturą tychże źródeł. W znacznie szerszym zakresie wyraża tę Deklaracja Stanów Zgromadzonych: „Wszystkie prawa dawne i teraźniejsze przeciwne niniejszej konstytucji lub któremukolwiek jej artykułowi znosiemy[...]"43. Choć wskazana regulacja nie stoi może na najwyższym poziomie legislacyjnym, jest przy tym nadzwyczaj lapidarna, reguluje jednak wprost charakter Ustawy rządowej (i „ustaw konstytucyjnych” ją uzupełniających) jako konstytucji formalnej, stojącej w hierarchii źródeł prawa wyżej od innych aktów prawnych obowiązujących w Rzeczypospolitej. Zadeklarowano tu wprost nieważność aktów niższego rzędu (czy choćby określonych ich przepisów) w przypadku ich sprzeczności z prawem zasadniczym. Dodatkowo Deklaracja przewidywała szczególną ochronę konstytucji: „dajemy pilne oko na ubeśpieczenie tey konstytucji, stanowiąc: ktobykolwiek śmieł być przeciwnym niniejszej konstytucji lub targać się na jej zepsucie [...] zasiewanie nieufności, przewrotne tłumaczenie konstytucji, a tym bardziej przez formowanie jakiegokolwiek w kraju rokoszu; ten za nieprzyjaciela ojczyzny, za jej zdrajcę, za buntownika uznany naj-

${ }^{41}$ Por. VL, t. 9, s. 220. W XVIII wieku zdarzało się, iż termin „konstytucja” występował też jako synonim pojęcia „organizacja”, tak np. F.S. Jezierski, O Bezkrólewiach $w$ Polszcze y wybieraniu królów. Po skończoney linii Jagiellońskiey Męskiey na osobie Zygmunta Augusta, aż do Naszych czasów, Warszawa 1790, s. 8, pisze o „konstytucji rządu”.

${ }^{42}$ VL, t. 9, s. 220.

${ }^{43}$ Ibidem, s. 225. 
surowszymi karami [...] ukarany będzie"44. Co istotne, penalizacja miała objąć nie tylko „targnięcie się na zepsucie” konstytucji tudzież zorganizowanie „rokoszu” przeciw niej, ale także jej „przewrotne tłumaczenie” czy „zasiewanie” względem niej „nieufności”. Szczególne zdziwienie $z$ perspektywy dzisiejszych standardów musi budzić fraza o karaniu tych, którzy śmieliby być przeciwnikami konstytucji. $Z$ punktu widzenia niniejszych rozważań ważne jest jednak to, iż Deklaracja przesądza wprost o nadrzędności Ustawy rządowej w systemie źródeł prawa, a więc o istnieniu hierarchicznej struktury tychże źródeł na podobieństwo systemu współczesnego, który choć bardziej rozbudowany i koherentny, zasadza się na analogicznym założeniu o konieczności zagwarantowania zgodności i niesprzeczności aktów niższego rzędu $z$ aktami wyższego rzędu, szczególnie $z$ konstytucją. Deklaracja, przewidując szczególną ochronę konstytucji na gruncie prawa karnego, sytuuje ją również symbolicznie w roli fundamentu organizacji prawnej i politycznej państwa i społeczeństwa. Warto dodać, że ustawa o sejmie wprowadzała mechanizm kontroli konstytucyjności projektów uchwał parlamentu - miała się tym zajmować stała komisja sejmowa ${ }^{45}$.

Oczywiście pojawiają się w literaturze głosy wskazujące, że Konstytucja 3 maja nie do końca odpowiada standardom współczesnych aktów konstytucyjnych. Chodzi tu przy tym nie tylko o oczywiste względy materialne (brak zasady równości wobec prawa, nierozstrzygnięcie, poza ogólnikową deklaracją, sprawy poddaństwa chłopów czy realne zmniejszenie liczby osób obdarzonych prawami politycznymi), ale także formalne. Wskazuje się w tym kontekście przede wszystkim na brak kompleksowej deklaracji praw obywateli ${ }^{46}$ czy też obecność w systemie anachronicznej instytucji pacta conventa ${ }^{47}$.

${ }^{44}$ Ibidem, s. 226.

45 Por. Z. Szcząska, Między konstytucjonalizmem stanowym a nowożytnym. Ustawa Rządowa na tle współczesnych ustaw zasadniczych, w: Ku reformie państwa i odrodzeniu moralnemu człowieka. Zbiór rozpraw poświęconych dwusetnej rocznicy ustanowienia Konstytucji 3 Maja 1791 roku, red. P. Żbikowski, Rzeszów 1992, s. 172.

46 Ibidem, s. 165-166.

47 J. Matuszewski, op.cit., s. 301. 
Nic nie zmienia jednak faktu, że akty prawne wchodzące w skład Konstytucji 3 maja w sposób relatywnie kompleksowy regulowały podstawowe zagadnienia ustroju państwa, były usytuowane hierarchicznie wyżej od innych aktów prawnych, a także, co w realiach Rzeczypospolitej szczególnie istotne, prawa zwyczajowego. System 3 maja zasadzał się przy tym na zasadzie formalnej praworządności opartej o gwarancje prawa pisanego, którego nie można było derogować lub modyfikować normą prawa zwyczajowego czy też odstępować od nich w oparciu o abstrakcyjne reguły racjonalności i słuszności (co stanowiło rys charakterystyczny systemu źródeł prawa Polski szlacheckiej). Uzupełnieniem tych zasad było $z$ pewnością usunięcie $z$ systemu prawnego zasady wypowiedzenia posłuszeństwa monarsze (przez odebranie społeczeństwu formalnej możliwości wypowiedzenia mu posłuszeństwa), a przede wszystkim zakazanie praktyki przejmowania legalnej władzy w państwie $z$ rąk uprawnionych organów przez instytucje tymczasowe, obywatelskie, „pozasystemowe” organizacje konfederacke ${ }^{48}$. W Polsce szlacheckiej tworzyły one w zasadzie alternatywny system organów władzy państwowej, który bywa w literaturze określany mianem „antysystemu” ustrojowego ${ }^{49}$.

W konsekwencji uważamy, że to dopiero Ustawę rządową z 3 maja 1791 roku (wraz z aktami ją uzupełniającymi) można określić jako pierwszą polską konstytucję. Inne twierdzenia, nawet użyte na potrzeby syntez podręcznikowych i traktowane jako dydaktyczne czy propedeutyczne uproszczenia, możemy za Matuszewskim określić mianem „lekkomyślnego promowania polskiego konstytucjonalizmu

48 VL, t. 9, s. 222.

49 Szerzej na temat relacji między organami i porządkiem prawnym konfederacji a zwyczajnymi organami i systemem prawnym państwa opisuje W. Stanek, Konfederacje generalne koronne w XVIII wieku, Toruń 1991. O teorii „antysystemu" ustrojowego patrz E. Opaliński, Kultura parlamentarna w Rzeczypospolitej XVII wieku, w: Między konstytucją Nihil Novi a ustawodawstwem nowoczesnych demokracji. Parlamentaryzm polski $w$ XVI-XX w. Materiały Ogólnopolskiej Konferencji Naukowej odbytej $w$ Radomiu $w$ dniach 12-13 października 2005 r., red. H. Gmiterek, S. Piątkowski i J. Wrona, Radom 2005, s. 35. Zob. T. Kucharski, Instytucja egzorbitancji, rozdz. 3, - tu uzasadnienie aprobaty dla stanowiska prof. Edwarda Opalińskiego. 
$\left[\ldots{ }^{\prime 50}\right.$. Dla istnienia ustawy zasadniczej w danym porządku prawnym konieczne jest bowiem, naszym zdaniem, istnienie zasady formalnej praworządności i to opartej na monopolu albo przynajmniej zdecydowanym i niepodlegającym wątpliwości prymacie prawa pisanego (tworzącego hierarchiczną strukturę względnie stałego i zamkniętego katalogu źródeł). Taka sytuacja absolutnie nie zachodziła w Polsce szlacheckiej, na co wskazują: rola prawa boskiego (do którego się odwoływano), prawa zwyczajowego, norm wynikających z konieczności czy słuszności (na podstawie których lekceważono lub wprost „uchylano” prawidłowo wydany przez upoważniony organ akt prawny) oraz stanowy partykularyzm prawny ${ }^{51}$. Niewątpliwie należy przy tym brać pod uwagę intencje twórców aktów prawnych w Rzeczypospolitej, którzy najczęściej nie myśleli o kompleksowo regulującym materię ustroju państwa akcie nadrzędnym, próbowali raczej rozwiązywać adhoc pojawiające się problemy i zagrożenia dla istniejącej struktury ustrojowej.

Pragniemy podkreślić, iż rolą historii prawa jest współdziałanie i służenie rozwojowi dziedzin naukowych, które uwidoczniono w nazwie tej dyscypliny, tzn. historii i prawa. W konsekwencji prace historycznoprawne mają z jednej strony wspierać tradycyjną historiografię za pomocą warsztatu prawniczego pozwalającego uzupełnić i skorygować te elementy badań nad historią polityczną, które wymagają wzięcia pod uwagę czynników natury prawnej. $Z$ drugiej strony historycy prawa winni wspierać badaczy i praktyków prawa pozytywnego, poszerzając ich perspektywę postrzegania fenomenów prawnych. Stąd jednym z absolutnie podstawowych wyzwań dla nowoczesnej historii prawa jest adekwatne odnoszenie współczesnych dokonań prawoznawstwa: pojęć, konstrukcji czy instytucji prawnych, do realiów historycznych w taki sposób, aby efektywnie szukać analogii bądź genezy takich zjawisk w przeszłości. Dlatego

50 J. Matuszewski, op.cit., s. 301.

${ }^{51}$ O szerokim traktowaniu przez szlachecką kulturę prawną istoty źródeł prawa oraz o braku hierarchii między normami prawa stanowionego (na przykładzie konstytucji sejmowych) zob. szerzej w innym miejscu, T. Kucharski, Konstytucje „egzorbitancyjne”, s. 127-137. 
tak ważna jest, po pierwsze, odpowiedzialność i ostrożność badawcza, a po drugie, rzetelne uzasadnianie stawianych tez ${ }^{52}$.

Reasumując, naszym zdaniem, dotychczasowe teorie o „konstytucjach” Polski przedrozbiorowej stanowią najczęściej dość lekkomyślne uwagi na marginesie prac badawczych, a nierzadko są motywowane ideologicznie, przez co nie spełniają podstawowych historycznoprawnych wymogów warsztatowych. W konsekwencji wprowadzają one sporo niepotrzebnego chaosu i to zarówno dla tradycyjnej historiografii, jak i nauki prawa konstytucyjnego.

\section{STRESZCZENIE}

Czy szlachecka Rzeczpospolita miała konstytucję? Przyczynek do rozważań nad wykorzystywaniem ustaleń nauki prawa konstytucyjnego do badań historii ustroju

Celem artykułu jest udzielenie odpowiedzi na pytanie, czy możliwe jest stosowanie pojęcia konstytucja do realiów epoki feudalnej. Opiera się on na analizie stosunków ustrojowych Rzeczypospolitej Obojga Narodów. Autor prezentuje poglądy badaczy, którzy twierdzą, iż pewne staropolskie akty prawne można uważać za konstytucje, począwszy od Artykułów henrykowskich z 1573 roku. Stara się przy tym krytycznie je ocenić w perspektywie wymogów, które powinien spełniać akt prawny o charakterze ustawy zasadniczej.

Słowa kluczowe: epoka feudalna, Rzeczpospolita Polsko-Litewska, nowoczesny konstytucjonalizm, ustawa zasadnicza (konstytucja).

52 Jak słusznie zauważyła ostatnio Paulina Święcicka w recenzji książki Jerzego Kolarzowskiego, kwestia stosowania współczesnej terminologii prawniczej i odnoszenia współczesnych konstrukcji prawnych do realiów historycznych jest zawsze ryzykowna i wymaga rzetelnego uzasadnienia. Por. P. Święcicka, Uwagi o metodzie badań historycznoprawnych. W związk $z$ rozprawą Jerzego Kolarzowskiego, „Idea praw jednostki $w$ pismach Braci Polskich. U narodzin nowożytnej koncepcji praw człowieka", Wydawnictwo Uniwersytetu Warszawskiego, Warszawa 2009, ss. 241, „Czasopismo Prawno-Historyczne” 2012, t. 64 , z. 1 , s. 233. 


\section{SUMMARY}

Is the noble Republic had a constitution? A contribution to the debate on the use of the findings of science in constitutional law to research the history of the body

The aim of the article is to answer a question: is it possible to use a term „constitution” for the reality of feudal times? Thesis of the article is based on an analysis of the political system of Polish-Lithuanian Commonwealth. The author presents views of the researchers, who are on the opinion that some of old-polish legal acts may be considered as constitutions, starting from the Henrician Articles from 1573. He tries to check those theories, and asses them critically in the light of requirements, which should be fulfilled by a Basic Law.

Keywords: feudal times, Polish-Lithuanian Commonwealth, modern constitutionalism, Basic Law (constitution).

\section{BIBLIOGRAFIA}

Akta sejmikowe województw poznańskiego i kaliskiego, t. 1, cz. 1, wyd. W. Dworzaczek, Poznań 1957.

Archiwum Główne Akt Dawnych w Warszawie, Archiwum Radziwiłłów, dz. II-62, s. 33-34 [149-150].

Banaszak B., Porównawcze prawo konstytucyjne współczesnych państw demokratycznych, Warszawa 2012.

Banaszak B., Prawo konstytucyjne, Warszawa 2008.

Biblioteka Zakładu im. Ossolińskich, sygn. 652/I, k. 263-281.

Dyskurs o eksorbitancyjach, w: Pisma polityczne z czasów panowania Jana Kazimierza Wazy 1648-1668 r., t. 3, Wrocław-Warszawa 1991, s. 336-361.

Grodziski S., Sejm dawnej Rzeczypospolitej jako najwyższy organ ustawodawczy. Konstytucje sejmowe - pojęcie i próba systematyki, „Czasopismo Prawno-Historyczne” 1983, z. 1.

Historia państwa i prawa polski, red. J. Bardach, t. 1 i 2, Warszawa 1971. Jezierski F.S., O Bezkrólewiach $w$ Polszcze y wybieraniu królów. Po skończoney linii Jagiellońskiey Męskiey na osobie Zygmunta Augusta, aż do Naszych czasów, Warszawa 1790.

Kallas M., Historia ustroju Polski, Warszawa 2005. 
Konopczyński W., Konwokacje, w: Studia historyczne ku czci Stanisława Kutrzeby, Kraków 1938.

Kucharski T., Instytucja egzorbitancji $w$ systemie prawno-ustrojowym Rzeczypospolitej Obojga Narodów, [w druku].

Kucharski T., Konstytucje „egzorbitancyjne” $w$ Rzeczypospolitej $w$ latach 1607-1648. Zarys problematyki, „Czasopismo Prawno-Historyczne” 2012, z. 2.

Kucharski T., Modyfikacja charakteru prawnego paktów konwentów po roku 1632, w: Ex contractu, ex delicto, z dziejów prawa zobowiązań, red. M. Mikuła, K. Stolarski, Kraków 2012, s. 89-109.

Lengnich G., Prawo pospolite Królestwa Polskiego, tłum. M. Moszczeński, t. 1, Kraków 1761.

Leśnodorski B., Dzieło Sejmu Czteroletniego 1788-1792: studium historyczno-prawne, Warszawa 1951.

Lewandowska-Malec I., Demokracje polskie. Tradycja - współczesność oczekiwania, Kraków 2013.

Łaszewski R., Salmonowicz S., Historia ustroju Polski, Toruń 2001.

Maciejewski M., Historia ustroju i prawa sądowego Polski, Warszawa 2011.

Makiłła D., Artykuły henrykowskie (1573-1576). Geneza - Obowiazywanie - Stosowanie. Studium historyczno-prawne, Warszawa 2012.

Makiłła D., Historia prawa $w$ Polsce, Warszawa 2008.

Matuszewski J., Czy podręcznik powinien być słuszny czy raczej dobry? W zwiazku z praca Mariana Kallasa „Historia ustroju Polski”, Wydawnictwo Naukowe PWN, Warszawa 2005, „Czasopismo Prawno-Historyczne” 2007, t. 58, z. 1 .

Minda M., Źródła i geneza prawa elekcyjnego w początkach Rzeczypospolitej Obojga Narodów - pisemna wersja referatu wygłoszonego na konferencji naukowej „Wolna elekcja w dawnej Rzeczypospolitej - procedura, przebieg, publicystyka” (materiał udostępniony dzięki uprzejmości organizatorów konferencji).

Naworski Z., Status Prus Królewskich w Rzeczypospolitej Obojga Narodów ewenement czy reguła, w: Rzeczpospolita państwem wielu narodowości i wyznań XVI-XVIII wiek, red. T. Ciesielski, A. Filipczak-Kocur, Warszawa-Opole 2008, s. 61-80.

Ochmann-Staniszewska S., Staniszewski Z., Sejm Rzeczypospolitej za panowania Jana Kazimierza Wazy, t. 1, Wrocław 2000.

Opaliński E., Kultura parlamentarna w Rzeczypospolitej XVII wieku, w: Między konstytucja Nihil Novi a ustawodawstwem nowoczesnych demokracji. Parlamentaryzm polski $w$ XVI-XX w. Materiały Ogólnopolskiej Konferencji Naukowej odbytej $w$ Radomiu w dniach 12-13 października 2005 r., red. H. Gmiterek, S. Piątkowski i J. Wrona, Radom 2005. 
Sobociński W., O ustawie konstytucyjnej Państwa Polskiego z roku 1573 r., „Czasopismo Prawno-Historyczne” 1948, t. 1.

Sobociński W., Pakta konwenta, Kraków 1939.

Stanek W., Konfederacje generalne koronne w XVIII wieku, Toruń 1991.

Szcząska Z., Między konstytucjonalizmem stanowym a nowożytnym. Ustawa Rządowa na tle wspótczesnych ustaw zasadniczych, w: Ku reformie państwa i odrodzeniu moralnemu człowieka. Zbiór rozpraw poświęconych dwusetnej rocznicy ustanowienia Konstytucji 3 maja 1791 roku, red. P. Żbikowski, Rzeszów 1992.

Święcicka P., Uwagi o metodzie badań historycznoprawnych. W zwiazku $z$ rozprawa Jerzego Kolarzowskiego, „Idea praw jednostki $w$ pismach Braci Polskich. U narodzin nowożytnej koncepcji praw człowieka”, Wydawnictwo Uniwersytetu Warszawskiego, Warszawa 2009, ss. 241, „Czasopismo Prawno-Historyczne” 2012, t. 64, z. 1.

Tarnowska A., Koncepcja nowoczesnego konstytucjonalizmu $w$ historii prawa, „Studia Iuridica Toruniensia” 2009, t. 5, s. 62-78,http://dx.doi. org/10.12775/SIT.2009.004.

Uruszczak W., Historia państwa i prawa polskiego, t. 1: 966-1795, Warszawa 2013.

Uruszczak W., Zasady ustrojowe Rzeczypospolitej Obojga Narodów, „Czasopismo Prawno-Historyczne” 2008, z. 2, s. 125-156.

Volumina Legum, t. 2-9, wyd. J. Ohryzko, Petersburg 1859-60. 